\title{
Problematic Analysis of Cash Waqf Management in West Sumatera through Analytic Network Process (ANP) Approach
}

\author{
Nil Firdaus ${ }^{1}$, Amiur Nuruddin ${ }^{2}$, Fifi Hasmawati ${ }^{3}$ \\ ${ }^{I}$ Ph.D Student of Shariah Economics, Islamic State University of North Sumatera, Indonesia \\ ${ }^{2}$ Lecturer in Shariah Economics, Islamic State University of North Sumatera, Indonesia \\ ${ }^{3}$ Lecturer Islamic State University of Raden Fatah Palembang, Indonesia \\ firdausnil83@gmail.com
}

\begin{abstract}
Implementation of good governance in cash waqf institutions is a must. But in its implementation in West Sumatra there are still various problems in governance which have an impact on not maximizing the collection of cash waqf. Through the Analytic Network Process (ANP) approach this study tries to answer several questions: (1) what are the priority issues of cash waqf management, (2) What are the priority solutions for cash waqf management and (3) what are the cash waqf management strategy in West Sumatra. The results showed that the priority of problems in cash waqf management in West Sumatra in priority order were Human Resources (0.371), regulation (0.243), accountability (0.200) and products $(0.184)$ with the rater agreement (W: 0.377). Priority results solutions with Human Resource solution sequences (0,367), regulator solutions (0.267), product solutions $(0.183)$ and accountability (0.181). The results of the rater agreement with the value (0.348). While the results of the strategy in the order of collaboration with the Tungku Tigo Sajarangan are the top priority with a value (0.366), public education about cash waqf (0.324) and nazhir guidance and mauquf alaih (0.308). The rater agreement value is equal to (W: 0.111).
\end{abstract}

Keywords : Management; waqf; Analytic Network Process (ANP).

\section{Introduction}

As a socio-economic instrument the waqf has played a role and made a major contribution to Islamic civilization. Early development of Islam gave waqf in the form of land, gardens, wells or other objects that are eternal in substance. But in the second century the Hijri began to be known as waqf in the form of dinars and dinars (both were the medium of exchange at that time).

Cash waqf was first used during the time of Utsman in Egypt at the end of the 16th century (1555-1823 M). During the Utsmani era in Egypt, the development use of Hanafi figh was in carrying out its business and social activities. Imam Muhammad al-Shaybani explained that even though there was no strong hadith support, the use of movable property as a waqf was permitted, if indeed it had become a general habit it was not always a requirement in the use of movable property as a waqf property

Nowadays the concept of cash waqf is re-emerging through the certificate cash waqf which was proposed by M.A Manan in 2000. This concept became the basic point in the development of cash waqf in the modern era in several Muslim countries, including Indonesia. As a country with a Muslim majority, of course, cash waqf have the potential to be developed in Indonesia. According to data from the Indonesian Waqf Board (BWI) in 2017 the potential for cash cash waqf in Indonesia reaches 120 trillion per year.

The potential is spread in various regions in Indonesia, including in West Sumatra with a potential of 3 Trillion per year. Various sectors strongly support the development of cash waqf in West Sumatra such as religious aspects and the value of local wisdom. But in its development, cash waqf in West Sumatra did not match what was expected. Achievement of the results of collecting cash waqf is only around 1.61 billion since 2009 until now. Of course 
this shows a variety of problems in collecting cash waqf. One important factor that causes the not achieving the maximum potential of waqf is the poor management of cash waqf institutions.

Various studies have explained the importance of good management in the institution of cash waqf. According to Hisham Yaacob (et. al) for example, explaining the progress of waqf institutions is very dependent on the management of the waqf institutions. Syadiyah Abdul Syukor explained that the integrity and reputation of waqf institutions had a direct impact on the trust of citizens which consequently led to the representation of cash. Che Zuina Ismail, et. al stated that effective and efficient asset management would be able to provide a wealth of basic resources for Muslims and improve the country's economy. Likewise, what was stated by Aam S. Rusydiana \& Abrista Devi when examining issues of cash waqf problems in Indonesia that one of the solutions to the problems of cash waqf in Indonesia is the application of good governance.

This study will explain the various problems of cash waqf management in Sumatra. So that the formulation of the problem is: (1) What are the problems of the management of cash waqf, (2) What are the priority solutions and (3) How the strategy for developing cash waqf in West Sumatra.

\section{Review of Literatures}

\section{The Definition of Cash Waqf}

Cash Waqf is a translation of the term وقف النقود. The term Cash Waqf was popularized in Bangladesh by M.A Manan. Cash waqf by definition is holding an amount of money by the waqf, whether individual, corporation, institution, company or private or public organization, and submitting the results of the cash waqf continuously for welfare. According to Law No. 41 of 2004, the meaning of cash waqf is waqf is a legal act of waqf to separate and / or surrender a portion of his property to be used forever or for a certain period in accordance with his interests for the purposes of worship and / or public welfare according to sharia.

\section{The Definition of Management}

The words of management come from English, namely management. Whereas the word management comes from the Latin word which is human which literally means by hand but also power and jurisdiction. At the end of the middle Ages the word maneggiare appeared in Italian, indicating official responsibility in production such as a textile factory workshop or trade office. The word evolved into French, maneherie and then to English management which was first noted for use in English in $1588 \mathrm{AD}$ At the end of the 18th century management became commonly used in English and the word means business organizations that employ people who His main task is to oversee the activities of others.

Griffin defines management as the process of planning and decision making, organizing, leading and controlling human, financial, physical and information organization resources to achieve organizational goals efficiently and effectively. ${ }^{1}$ Koontz \& Donnel mentioned that management is an effort to achieve the desired goals by building a pleasant work environment through the people employed and organized groups.

The definition of management according to Islam is not much different from economics. Management is considered both a science and an art of leadership. According to Ahmad Ibrahim Abu Sinn, management is seen as knowledge that is collected, synthesized and

\footnotetext{
${ }^{1}$ Griffin, Ricky W, Management (Boston: Houghton Mifflin Company, 1990), P. 6.
} 
accepted in relation to universal truths about management. In the art of management is defined as a creative personal strength coupled with skills in implementation. Management is an art organizer and user of human talent. Management is also interpreted as a series of integrated steps to develop an organization as a technical economic system.

\section{Research Methods}

\subsection{Types and Sources of Data}

This research is a quantitative-qualitative study that aims to provide views sourced from respondents (experts, practitioners and regulators). The data used are primary data obtained from the results of in-depth interviews with cash waqf experts and practitioners in West Sumatra who understand the issues discussed. Then proceed with filling out the questionnaire in the form of pairwise comparison by respondents who amounted to 9 people ( 3 experts, 3 practitioners and 3 regulators).

\subsection{Data Analysis Techniques}

The analytical method applied in this study is a qualitative-quantitative analysis method. The analytical tool used in this study is the ANP method using Super Decision software. The Analytic Network Process (ANP) is the most comprehensive framework for the analysis of community, government and company decision making available today to decision makers. This allows one to enter all the factors and criteria, real and not real that must be taken to make the best decision. ANP allows interaction and feedback within group elements (inner dependence) and between groups (external dependency). Such feedback best captures the complex effects of interaction in society, especially when risks and uncertainties are involved. There are several steps that must be done in order to obtain this ANP research data. In general, the stages can be seen in the following table 1:

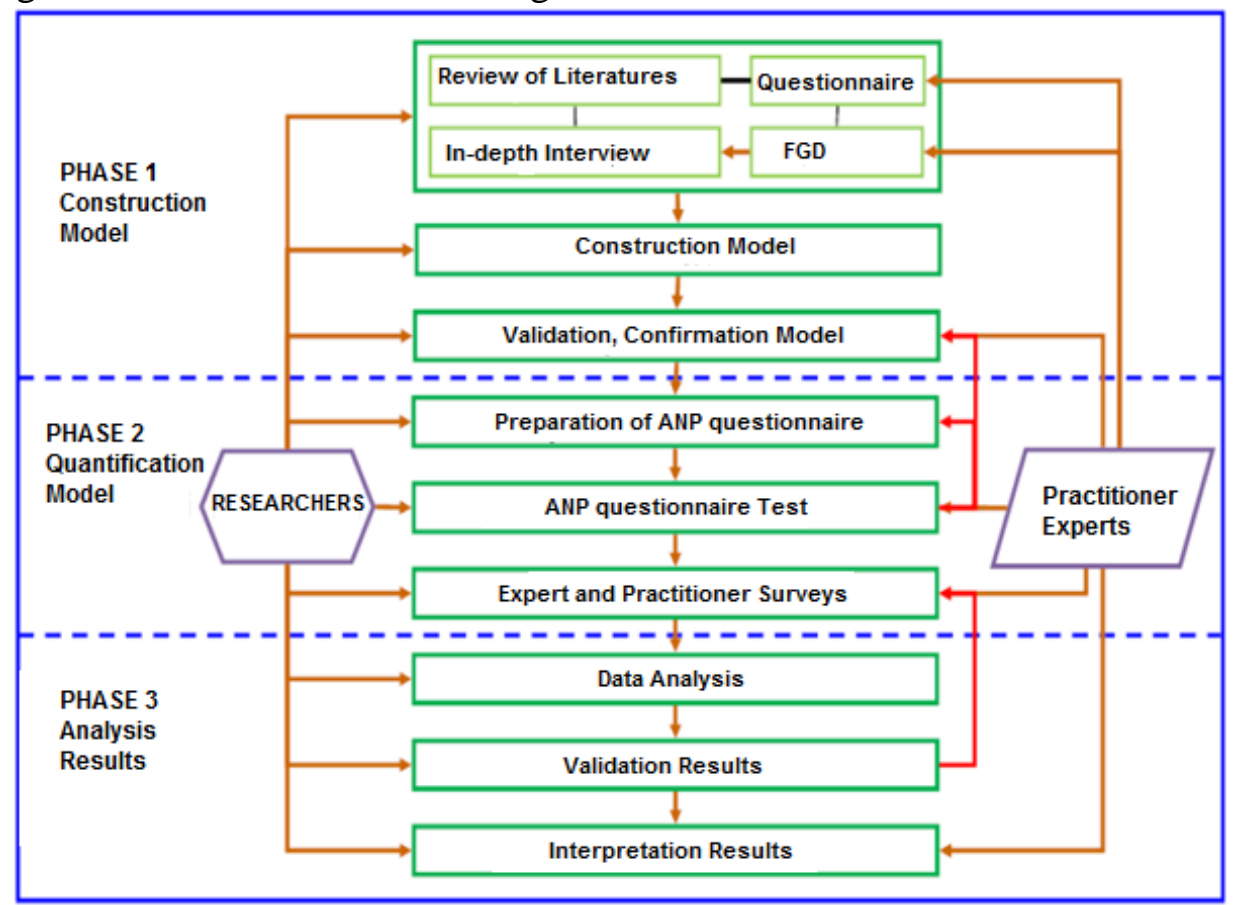

Source: Ascarya (2010) 
The First Phase is the construction of models based on theoretical and empirical review literature and provides questions to experts and practitioners. Then an in-depth interview is conducted to examine information more deeply to obtain problems and solutions.

The Second Phase is the quantification model in which the results of the ANP framework that have been formed in the first phase are then structured questions. Questions at this stage are pairwise comparisons between elements in the cluster to find out which of the two has greater influence (more dominant) and how big the difference is through the 1-9 numerical scale.

While the Third Phase of Synthesis Analysis aims to analyse the data that has been inputted in the Super Decision software then transferred and processed in Microsoft Excel. The results of this synthesis analysis aim to determine the Geometric Mean and Rater Agrrement (W).

a. Geometric Mean aims to determine the results of individual assessments of the respondents and determine the results of opinions in one group carried out an assessment by calculating the geometric mean. Pairwise comparison questions from respondents will be combined to form a consensus. Geometric mean is a type of average calculation that shows a certain tendency or value which has the following formula.

$$
\left(\prod_{i}^{n}=1 a_{1}\right)^{1 / n}=\sqrt[n]{a_{1} a_{2} a_{n}}
$$

b. Rater agreement is a measure that shows the level of agreement of the respondents (R1$\mathrm{Rn})$ to a problem in one cluster. The tool used to measure the rater agreement is Kendall's Coefficient of Concordance (W; $0<\mathrm{W} \leq 1$ ). $\mathrm{W}=1$ shows perfect conformity (Ascarya, 2010). To calculate Kendall's (W), the first is to rank each answer then add them up.

$$
R_{1}=\sum_{j}^{m}=1 r_{i, j}
$$

Nilai rata-rata dari total ranking adalah

$$
R=\frac{1}{2} m(n+1)
$$

Jumlah kuadrat deviasi (S), dihitung dengan formula:

$$
S=\sum_{i}^{n}=1\left(R_{i}-\bar{R}\right)^{2}
$$

\section{Discussion}

\subsection{Results of the ANP Framework}

Based on the literature review sourced from journals and books relating to the study of the management of cash waqf, an in-depth interview was conducted with experts and practitioners of cash waqf in West Sumatra. The purpose of this in-depth interview is to form the ANP framework in accordance with the development of cash waqf in West Sumatra. 
Table 2. Ape shape

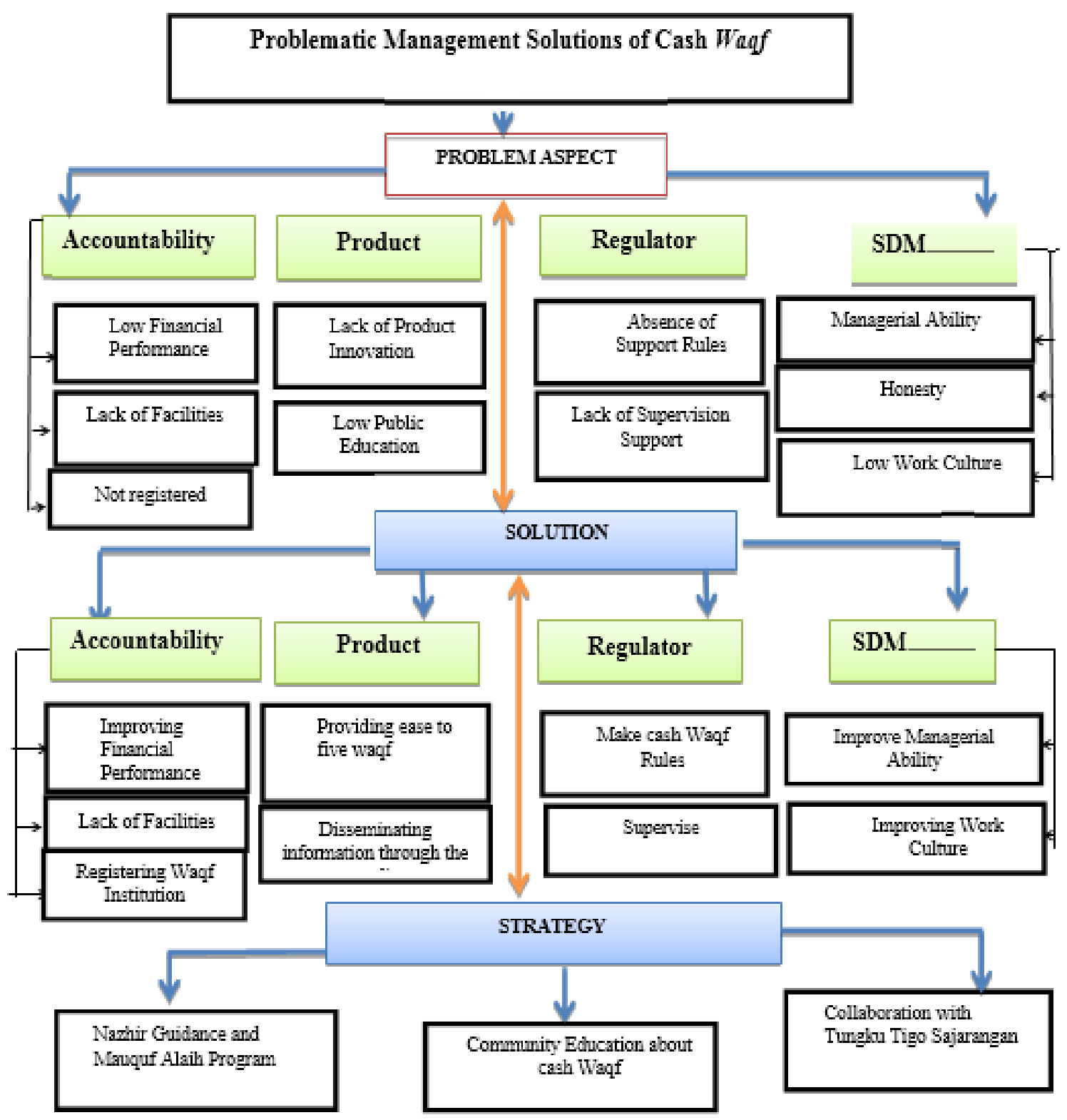

Source: compiled from various literature reviews

\subsection{Results of Problem Clusters Analysis}

According to all respondents, the priority order of cash waqf management problems is SDM (0.371), regulator (0.243), accountability (0.200) and product (0.184). The value of the rater agreement is equal to (W: 0.377 ) meaning that the respondent's answer varies so that the respondent's agreement value is low, as in Figure 2.1 below: 


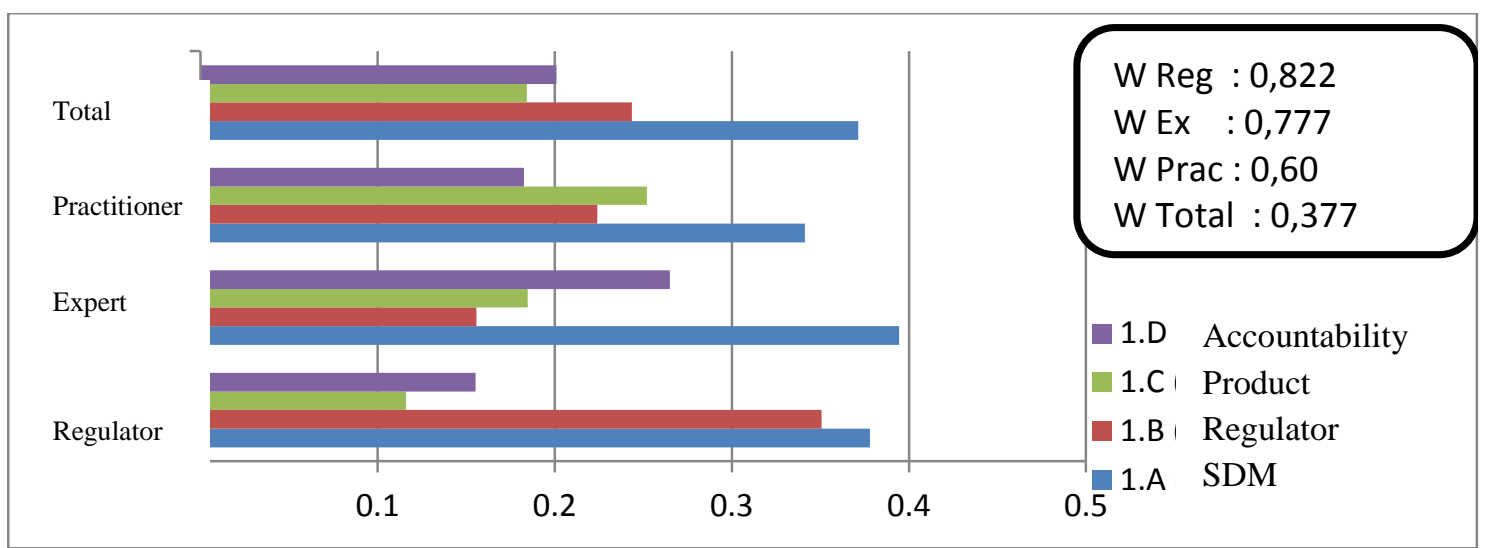

Figure 1. Results of Priority of Overall Problems of Respondents

Based on the group of respondents (regulators, experts and practitioners) the results of cluster synthesis are found where the regulator gives priority assessment of SDM (0.378) regulator support $(0.350)$, accountability $(0.155)$ and product problems with value $(0.116)$ with the level of respondent agreement (rater agreement) of (W: 0.822). According to experts the priority problem is also SDM with a value (0.394), accountability (0.262), product (0.184) and regulator problems by (0.155). Rater agreement of (W: 0.777$)$ which shows the high suitability of respondents. According to practitioners also SDM with grades (0.341), Products (0.252), regulators $(0.224)$ and accountability $(0.182)$. Rater agreement is (W: 0.60$)$ indicating the high correspondence of respondents.

\subsection{Results of Solution Cluster Analysis}

According to the overall respondents give priority to the management of cash waqfsolutions namely SDM solutions (0.367), regulator solutions of $(0.267)$, product solutions $(0.183)$ and finally accountability $(0.181)$. The results of the rater agreement show the low agreement of all respondents with a value (0.348).

Based on the respondent group, according to the respondent group, according to the regulator in the order of solutions the problem of regulator support (0.384), SDM (0.369) accountability solutions $(0.137)$ and product solutions $(0.108)$. The result of the rater agreement is (W: 0.822) which shows the high agreement of the respondent regulators. In contrast to regulator respondents, according to experts in the priority order of SDM solutions (0.410), accountability solutions $(0.213)$, product problem solutions $(0.195)$ and priority regulator solutions (0.181). The rater agreement value of (0.644) shows the high agreement of respondents in determining the priority of fundraising solutions. Meanwhile, according to practitioners in the order of priority SDM solution solutions (0.321), product solutions (0.247), regulator solutions (0.238) and accountability solutions (0.192). The result of the rater agreement shows the low agreement of respondents, namely (W: 0.288), meaning that the respondents' answers to practitioners were more varied as in Figure 2 below: 


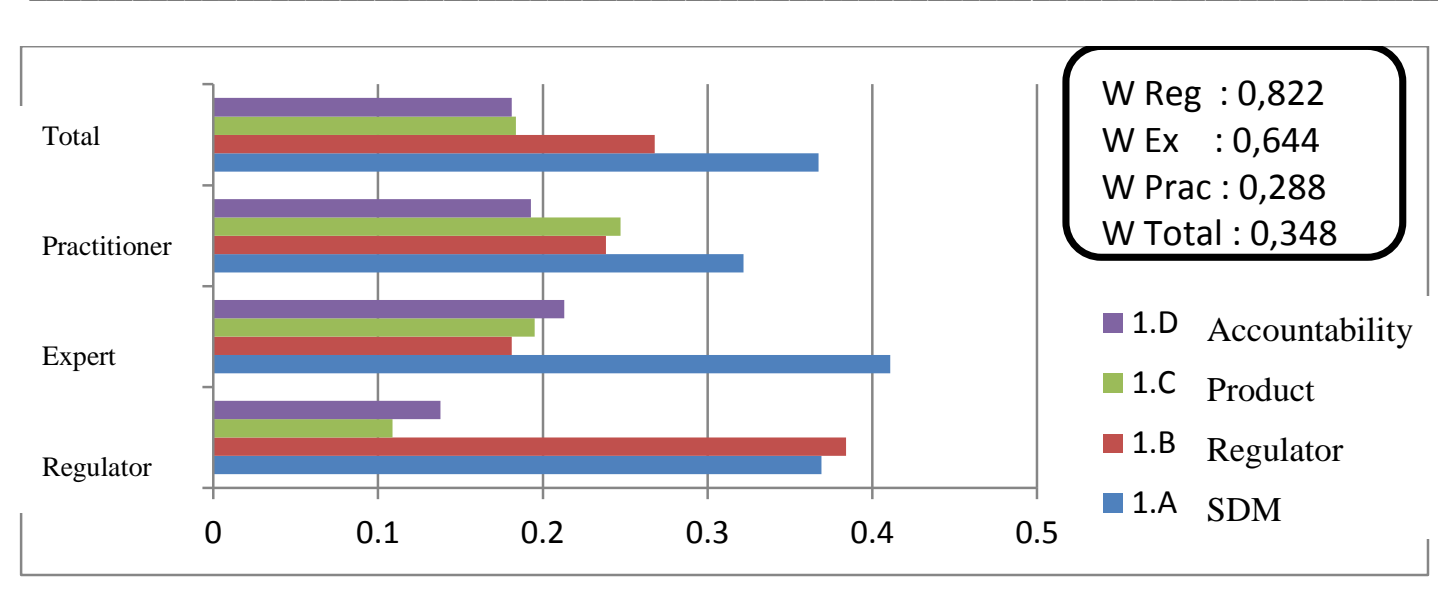

Figure 2. Priority of Cash waqf Management Solutions

\subsection{Results of Strategy Cluster Analysis}

The synthesis results show that the majority of respondents stated that cooperation with the Tungku Tigo Sajarangan is a top priority with a value (0.366), public education about cash waqf (0.324) and guidance of Nazir and mauquf alaih (0.308). The value of the rater agreement is (W: 0.111) which indicates the low agreement of respondents.

Based on the assessment of each respondent the results were found, according to the Regulator in collaboration with the Tungku Tigo Sajarangan (0.408), Nazir guidance and mauquf alaih (0.301) and public education (0.290). The results of the rater agreement stated the low agreement among respondents with a value (W: 0111). Expert respondents gave priority assessments namely community education (0.380), guidance of Nazir and mauqu alaih (0.340) and cooperation with the Tungku Tigo Sajarangan (0.278). The result of the rater agreement is low with a value (W: 0 ). According to practitioners the priority of the strategy is cooperation with the Tungku Tigo Sajarangan (0.458) Nazir guidance (0.353) 0.336 community education. The result of the rater agreement is also very low with a value (W: 0.006 ) as in Figure 2.3 below:

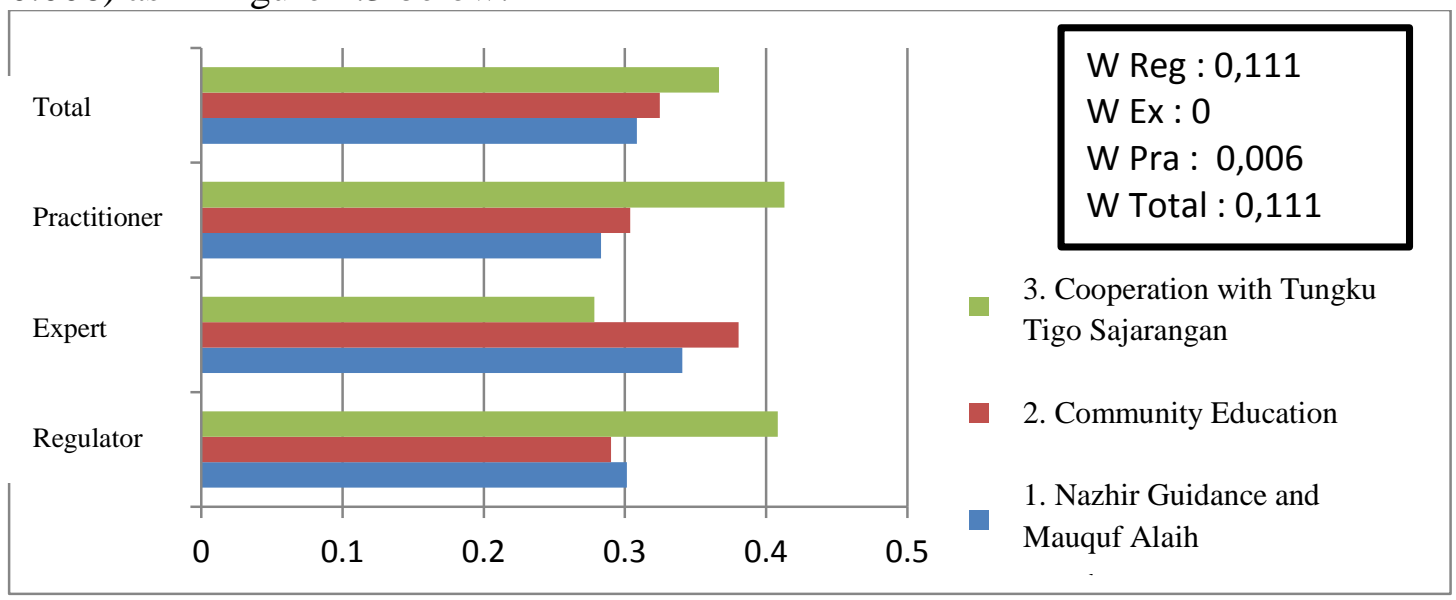

Figure 2.3. Priority in Cash Waqf Management Strategy in West Sumatra 


\subsection{Results of Specific Synthesis Analysis}

a. Results of Cluster Analysis of Cash Waqf Management Problems

\section{1) Accountability Cluster}

There are several nodes in the cluster of accountability issues, namely low financial performance, lack of facilities and the lack of registration of waqf. After analyzing it was found that according to the overall results of the overall respondents stated the priority problems of sub-accountability is the low financial performance (0.455), lack of facilities $(0.320)$ and the lack of registration of waqf institutions (0.223). While the results of the rater agreement are (W: 0.322), meaning that the respondent agreement level is still low

Based on the respondent group assessment of accountability issues it is known that according to the regulator there is no registered waqf institution (0.398) as the main priority, followed by low financial performance (0.382) and lack of facilities $(0.218)$. The value of the rater agreement is (W: 0, 172), which indicates the extent of the respondent's agreement. According to the expert, the ranking of financial performance is low (0.493), there is no registered waqf institution $(0,342)$ and lack of facilities $(0.165)$. The value of the rater agreement is (W: 0.777) which shows the high agreement of respondents in determining the priority of accountability issues. According to practitioners in the order of low financial performance (0.493), lack of facilities (0.286) and lack of registration of waqf institutions (0.220). Rater agreement (0.390) shows the low agreement of the respondents in determining the priority of the accountability problem with a value (W: 0.390) as in Figure 3.1 below:

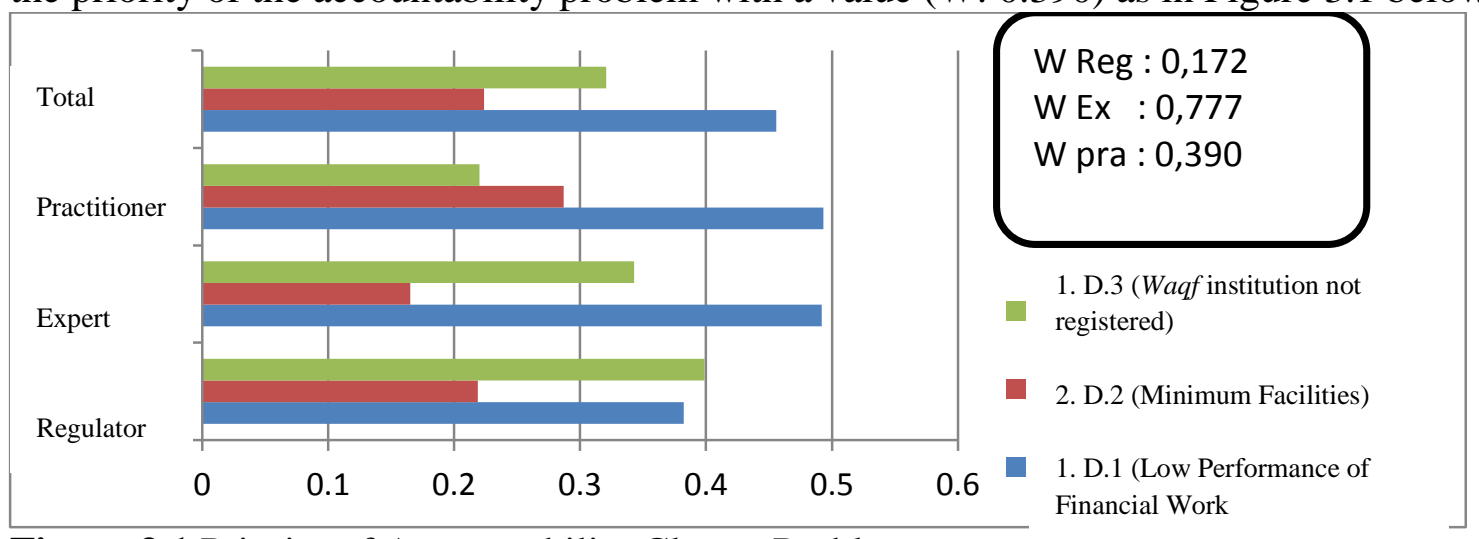

Figure 3.1 Priority of Accountability Cluster Problems

2) Product Cluster

The priority order of product problems according to the whole respondent is the low level of product socialization to the public (0.639) and waqf product innovation problems $(0.36)$. The rater agreement value of (W: 0.197) shows the low agreement of respondents.

According to the respondent group giving priority to product clusters namely low education to the community with a value (0.616) and lack of product innovation (0.383). Rater agreement value of (W: 0.1) shows the low agreement of respondents. According to experts with the priority problem is low education of cash waqf with value (0.785) and product innovation problems with value (0.214). Rater agreement is (W: 1) meaning that all respondents agreed to determine the priority of the product problem. Meanwhile, according to practitioners, low education to the community with a value $(0.516)$ is the first priority followed 
by product innovation ( 0.483$)$. This diversity shows the low agreement of respondents so that the value of the rater agreement is only (W: 0) like Figure 3.2 below:

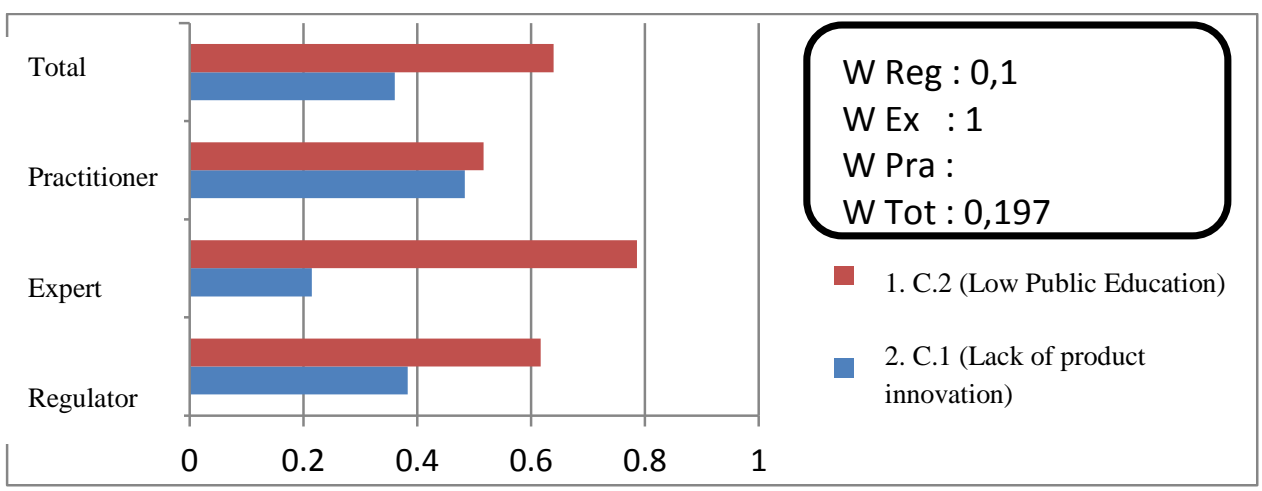

Figure 3.2: Priority of Cluster Product Problems

3) Regulator Cluster

All respondents stated that the absence of rule support is a priority issue in the regulator cluster with a value of 0.625 . While the absence of supervisory support has a value of 0,374 . The results of the rater agreement amounted to (W: 0.308) which shows the low suitability of the respondents' agreement.

The ranking order according to the grouping of respondents found that according to the regulator with the lack of rule support amounting to the value (0.655) and the lack of regulator supervision by the value (0.344). Rater agreement equal to (W: 0.444$)$ means that the respondents' answers were varied. According to the expert in the order there is no rule support from the regulator with a value (0.583) and a lack of supervisory support with a value (0.416). The results of the rater agreement amounted to (W: 0.111 ) indicating the variety of respondents' answers. Whereas according to the Practitioners is the lack of support of rules with a value (0.638) and the lack of supervision support with a value (0.361). Rater agreement equal to (W: 0.444 ) but shows the high agreement of respondents. The results of the analysis of the synthesis of the respondent and rater aggregation groups can be seen more clearly in Figure 4 below:

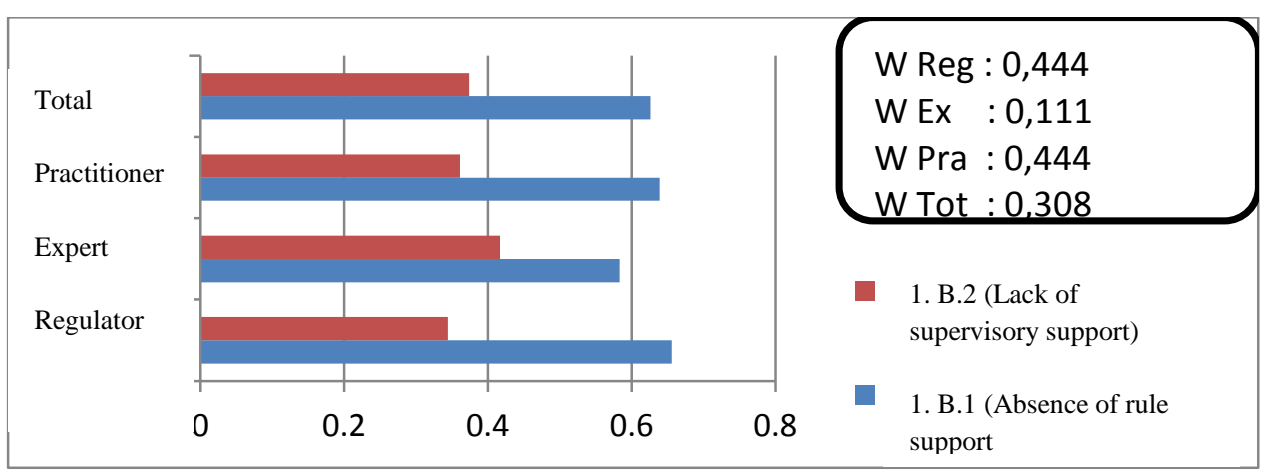

Figure 4. Priority of Regulator Cluster Problems

4) SDM Cluster

The average order of results of all respondents was lack of managerial ability (0.368), honesty (0.335) and low work culture (0.296). The results of the rater agreement amounted to 
(W: 0.012) indicating the suitability of respondents 'answers was very low with the variety of respondents' answers.

Respondent groups give priority, according to regulators with priority values of low managerial ability (0.439), honesty (0.294) and low work culture (0.265). Rater agreement equal to (W: 0.111) means the low suitability of the respondent's answers. According to the expert in the order of honesty and the low work culture is a matter of mutual priority (0.389) and low managerial ability (0.220). Rater agreement value of (W: 0298) shows the low suitability of respondents. According to practitioners with an assessment of low managerial ability (0.445), honesty ( 0.321$)$ and low work culture (0.232). The results of the rater agreement amounted to (W: 0.333 ) indicating the low suitability of respondents. like the following figure 5 .

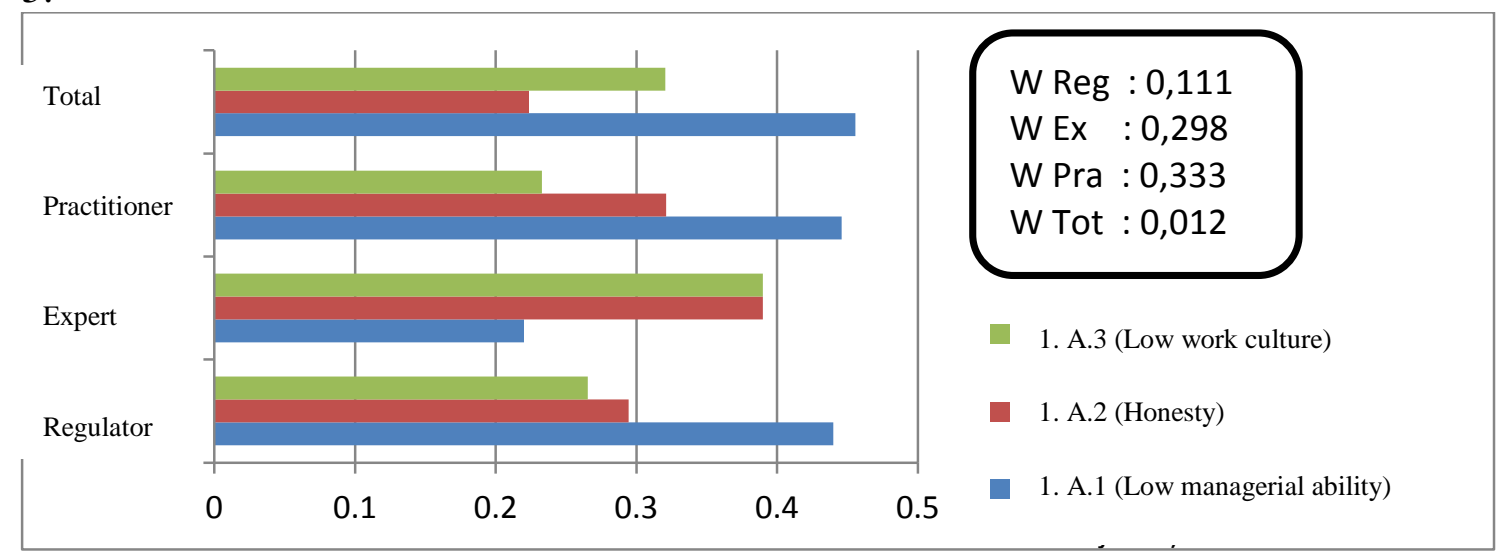

Figure 5. Priority of SDM Cluster Problems

b. Analysis Results of Solution Cluster in Cash waqf Management

\section{1) Accountability Solution Cluster}

The priority sequence of the results of the overall synthesis of respondents stated that registering institutions to BWI (0.374), improving financial performance (0.373) and improving facilities (0.252). The results of the rater agreement amounted to (W: 0.322) indicating the low suitability of all respondents.

Based on each respondent, the results of priority accountability solutions are found according to the legality regulator, the institution (0.474) is the main priority, followed by improving financial performance (0.312) and completing facilities $(0.213)$. The value of the rater agreement is (W: 0.333) indicating the low agreement between respondents in determining the priority of the accountability solution. According to experts in the order of registering waqf institutions with BWI (0.443), improving financial performance $(0.364)$ and completing waqf facility facilities (0.192). The result of the rater agreement is (W: 0.527) indicating the high respondent agreement value. Meanwhile, according to practitioners, the priority order is to improve financial performance (0.531), register institutions $(0.287)$ and (complete facilities (0.181). Rater agreement of (0.777) indicates the high agreement of practitioners' respondents in determining accountability priorities. seen in Figure 6 below: 


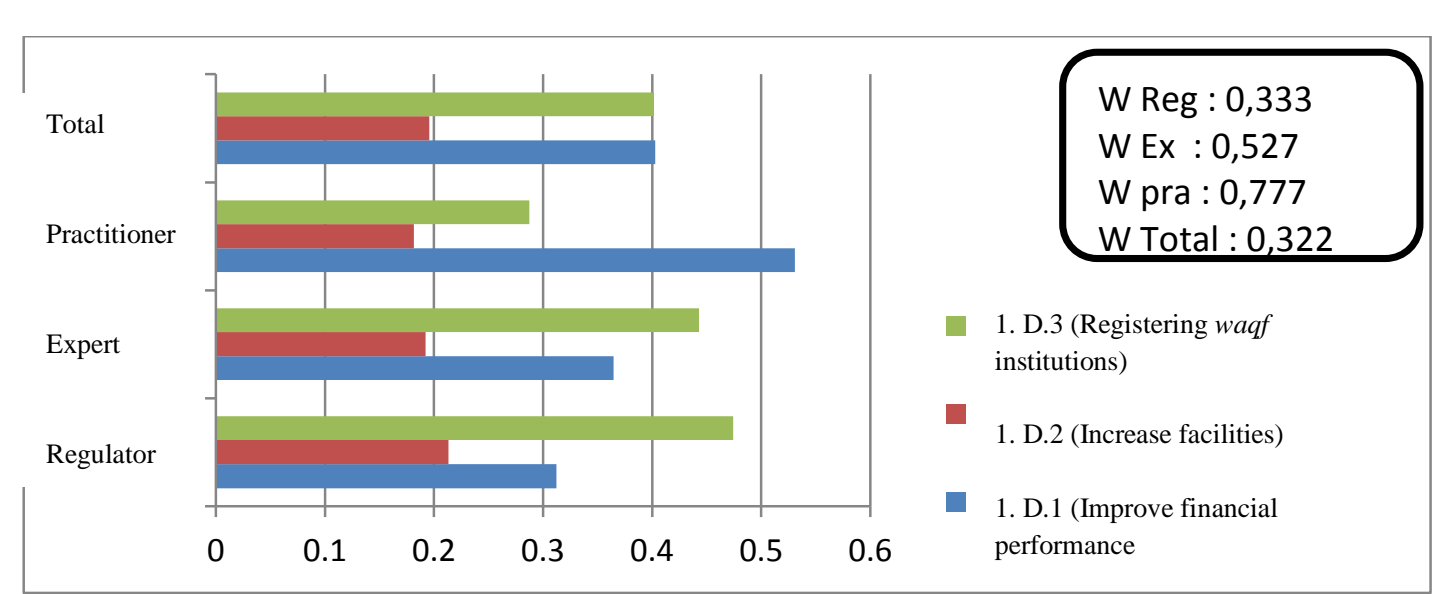

Figure 6. Solution Priority of Accountability Cluster

\section{2) Product Solution Cluster}

The overall priority order of respondents stated that socialization through the media (0.627) and innovating products (0.372). The result of the rater agreement is (W: 0.308 ) meaning that the respondent's suitability is still low in determining the priority of the product solution.

Based on the respondent group, the regulator agreed to state in the order of the dissemination of cash waqf through the media $(0,800)$ and innovation of waqf products $(0.199)$. The agreement of the tSDMee respondents of this regulator shows the perfect suitability in the priority of product solutions so that the value of the rater agreement is (W: 1). The expert also states in the order of the socialization of cash waqf $(0.583)$ and innovation of waqf products (0.416). The variety of respondents' answers shows the low suitability of respondents in determining priorities, so the value of the rater agreement is equal to (W: 0.111 ). While the views of practitioners with the order of the dissemination of cash waqf $(0.527)$ and innovation of waqf products $(0.472)$. The results of the rater agreement show the low suitability of respondents in determining the priority of product solutions that is equal to (W: 0.222). In general, the assessment of respondents can be seen in Figure 2.6 below:

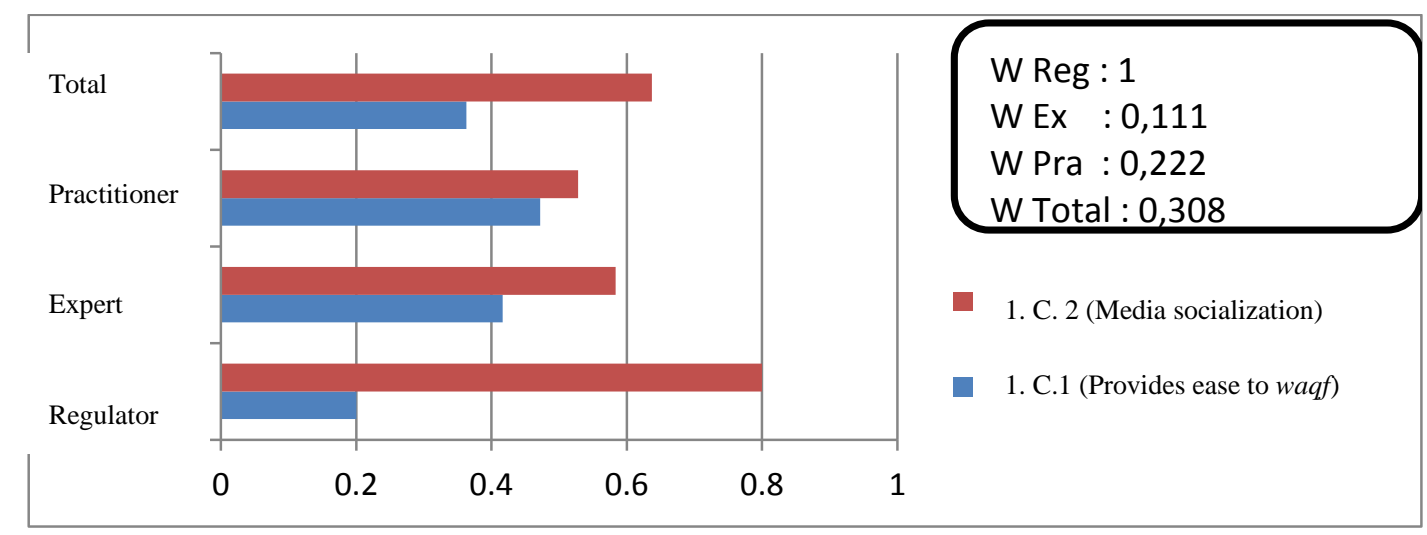

Figure 7. The Priority of Product Solution 


\section{3) Regulator Solution Cluster}

The results of the overall analysis of respondents who stated that the priority order of the sub-regulator is to form rules / policies (0.677) and conduct oversight $(0.322)$. The result of the rater agreement shows that the respondent's agreement is high, with a value (W: 0.444$)$.

Based on the respondent group, according to the regulator all tSDMee agreed to state that support in the form of rules (0.811) was the main priority followed by support in the form of supervision (0.188). The agreement of the tSDMee respondents showed the perfect suitability of the respondent's answers so that the rater agrrement value was (W: 1). According to experts also with the order of support in the form of rules (0.528) and support in the form of rules (0.416). The expert respondents' answers were more varied so that they showed a low rater agreement value (W: 0.111). Whereas the Practitioners also stated that they gave an assessment of support in the form of rules (0.638) and support in the form of supervision (0.361). The value of the rater agreement is (W: 0444) which shows the high level of respondent's confidence in determining priorities, as in Figure 8 below:

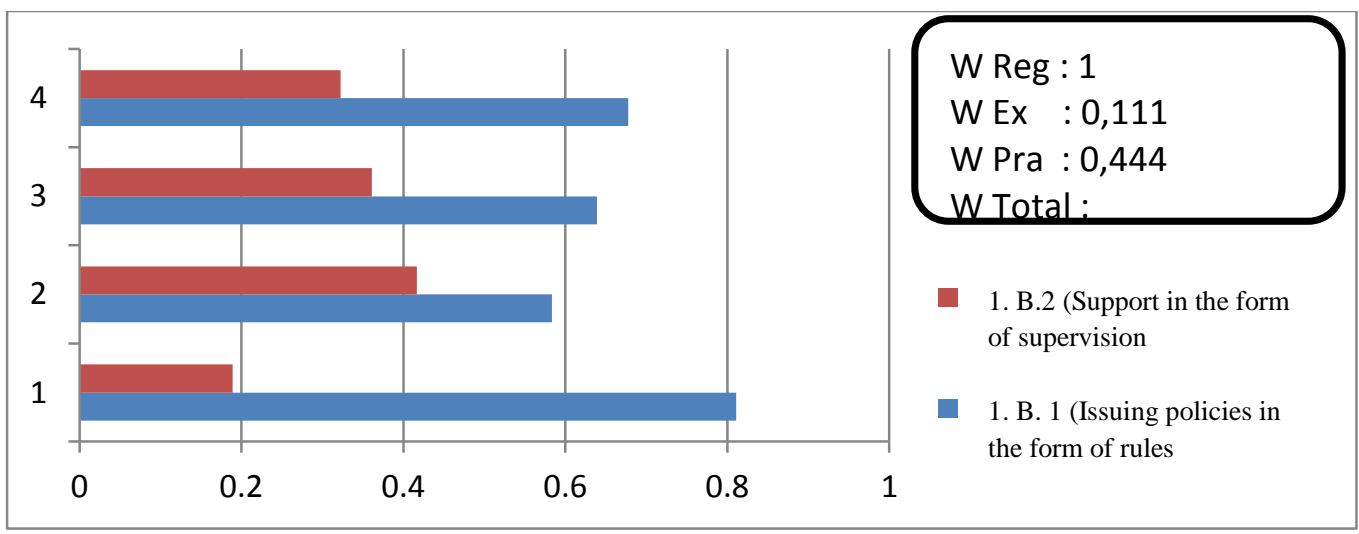

Figure 8. Priority of Regulator Solution

\section{4) SDM Cluster}

According to the overall respondents the main priority solutions to SDM problems are improving financial performance (0.627) and improving work culture (0.374). The value of the rater agreement is (W: 0.111) indicating the low agreement of respondents in determining SDM solutions.

The order of priority assessment according to the group of respondents is known that, regulators improve financial performance $(0.627)$ and improve work culture $(0.372)$. The value of the rater agreement is perfect, that is $(\mathrm{W}: 1)$. According to the expert improving financial performance has a value (0.500) and improving work culture by value (0.499). This shows the variety of respondents' answers to the priority of SDM problem solutions so that the agrarian rater is (W: 0 ). According to practitioners the main priority is to improve financial performance (0.638) followed by improving work culture (0.036). The result of the rater agreement is (0.444) which shows the high agreement of respondents in determining SDM priorities, as in Figure 9 below: 


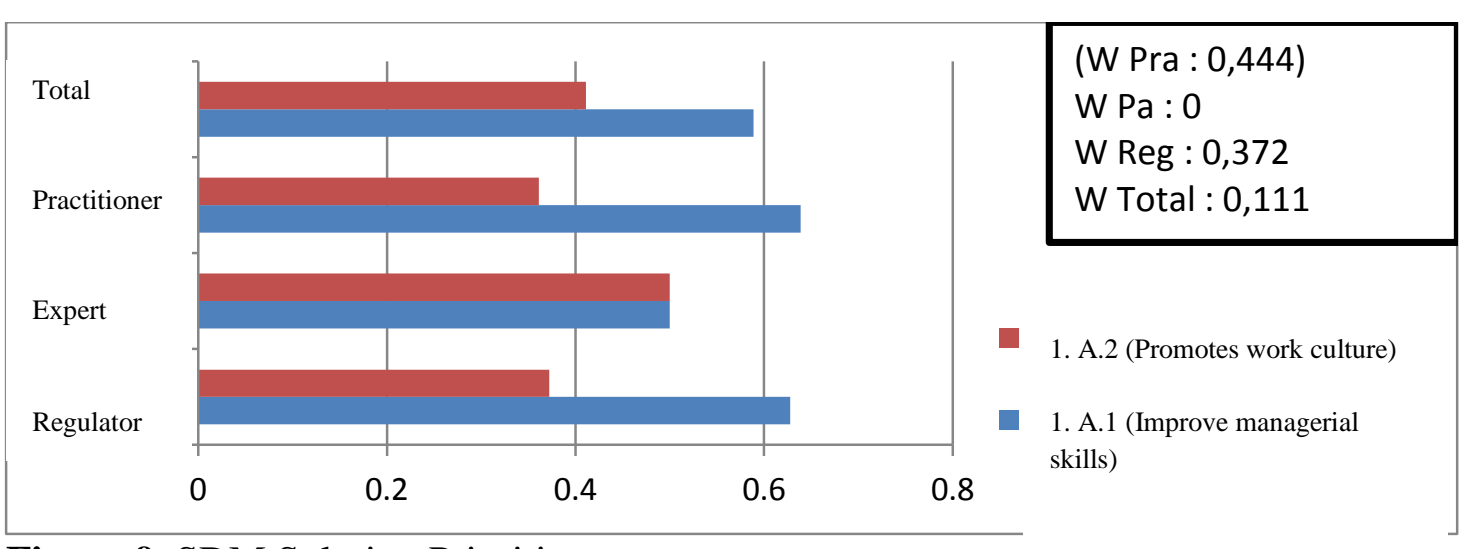

Figure 9. SDM Solution Priorities

\section{Conclusion}

One important factor that has become a problem in the development of cash waqf in West Sumatra is the management of waqf institutions. The priority issues analyzed by the ANP approach are SDM issues, regulation, accountability and waqf product problem themselves. While the priority of solutions, SDM improvement is also the main solution, followed the regulator solution 0.267 , product solutions $(0.183)$ and accountability solutions $(0.181)$ This shows the importance of professional nazhir in managing cash waqf. This shows the importance of realizing professional Nazis in managing cash waqf.

The cash waqf management strategy in West Sumatra is a collaboration with the Tungku Tigo Sajarangan, followed by public education about cash waqf, nazhir guidance and mauquf alaih (0.308). This shows that cash waqf institutions need to develop the values of local wisdom, especially the family leadership system in Minangkabau. Besides that it also teaches the importance of cooperation inter institutions so that the potential for cash waqf can be absorbed as much as possible.

\section{References}

Abdul Shukor, Syadiah, et.al, 2018. Trust on A waqf Institutions: Evidence from Malaysia, Islamic Marketing

Abū as-Su'ūd, Muhammad. 1997. Risālatu fì Jawāzi al-Waqfi an-Nuqūd, Beirut: Dār IbnHazm.

Burhanudin. 1994. Analisis Administrasi Manajemen dan Kepemimpinan Pendidikan , Jakarta: Bumi Aksara.

Cizakca, Murat. 2004. Ottoman Cash Waqf Revisited: The Case of Bursa 1555-1823, United Kingdom: FSTC,

Griffin, Ricky W. 1990. Management. Boston: Houghton Mifflin Company,).

Hofstede, Greet. 1993. "Cultural Contraints in Management Theories," in Academy of Managemen Executive, Vol. 7, No. 1.

Ibrahim Abu Sinn, Ahmad. 1981. al-Idārah fi al-Islām. Dubai: al-Matba'ah al-AsSDMiyah Ismail Abdel Mohsin, Magda. 2013. "Financing Through Cash-Waqf: a Revitalization to Finance Different Needs," in Islamic and Middle Eastern Finance and Management, Vol. 6 Issue: 4 , 
MIA Muhsin, et. al. 2016. Developtment and Administration of Institution of Waqf : Financing The Development of Old Waqf Properties New York : Palgrave Macmillan.

Mashitoh Mahamood, Siti \& Asmak Ab Rahman. 2015. Financing Universities Through Waqf, Pious Waqf: is it possible? Humanomics, Vol. 31.

Masyita, Dian. 2002. "Sertifikat Wakaf Tunai Sebagai Salah Satu Instrument alternative Pengentasan Kemiskinan di Indonesia," dalam Usahawan, No. 09 TH, XXXI

Nuruddin, Amiur. 2007. Peranan Tungku Tigo Sajarangan pada Masyarakat Minang Kabau dalam merekat Kesatuan Bangsa, dalam Jamuan Ilahi: Pesan al-Quran dalam berbagai dimensi Kehidupan. Bandung: Cita Pustaka Media.

Prayitno, Irwan, BWI Sumber harus optimalkan Pengembangan Aset Wakaf Uang, dalam http://www.bwi.or.id/index.php/publikasi/berita-mainmenu-109/978-bwi-sumbarharus-optimalkan-pengembangan-aset-wakaf Accessed on 22 June 2017.

Rozalinda, Ketua Badan Wakaf Indonesia (BWI) Sumatera Barat, wawancara di Padang, tanggal 18 Oktober 2017.

Rozan W Saaty. 2003. The Analitical hirarci Procces for Decision Making and The Analilical Network Proccess (ANP) for Decision Mekaing with Dependence and Feddback. University of Pittsburgh: Creative Decisions Foundation.

Slamet Rusydiana, Aam \& Abrista Devi. 2017. "Analsis Pengelolaan Dana Wakaf Uang di Indonesia: Pendekatan Analitic Network Proccess, dalam AL-AWQAF,

Yacoob, Hisyam, et.al, Accountability through accounting and reporting lense: Lessons from an awqaf institution in a Southeast Asia country, Humanomics, Vol. 31.

Zuina Ismail, Che, et.al, Challenges and Prospects of Cash Waqf Development in Malaysia, dalam Journal of Basic and Applied Scientific Research 4(2)340-348, 2014. 